\title{
The Eldari tick Ixodes eldaricus (Acari: Ixodidae) in Israel: its occurrence, morphometric and biological characteristics
}

\author{
Igor USPENSKY (1)
}

\begin{abstract}
A. Silberman Institute of Life Sciences, The Hebrew University of Jerusalem, Israel
e-mail: igorusp.acarina@gmail.com
\end{abstract}

ABSTRACT: An isolated population of the Eldari tick Ixodes eldaricus Dzhaparidze was studied in the southernmost part of the tick range (western surroundings of Jerusalem, Israel). Unfed adult and nymphal ticks were active from November through April. Ticks could be collected by flagging only from the grass just above the earth. A bimodal activity pattern was observed for adults with a decline in January characterized by the lowest air temperatures. Nymphal ticks had smaller size of their scutum as compared with specimens from the main part of the range. No mating adults were found during survey but when placed in a tube, males and females were immediately observed in the mating position. No tendency to attack humans or attach to them were registered in the field or in laboratory experiments. While having no apparent epidemiological significance, I. eldaricus deserves attention because of its possible role in epizootiology of rickettsial infections, which are common in the area of the survey.

Keywords: Ixodes eldaricus, redikorzevi group, season of tick activity, tick size and weight, mating, human affinity, epizootiology, Israel.

Zoobank: http://zoobank.org/C6F88386-7412-4AD9-B461-28C9D9409A01

\section{INTRODUCTION}

In the last decades, the interests of acarologists have been concentrated on about 20-25 tick species of clear medical or veterinary importance (Uspensky, 2006). Hundreds of other species have been favored with researcher's attention only occasionally, if at all. The Eldari tick, Ixodes eldaricus Dzhaparidze, 1950, is one of such scarcely studied species. The species was described based on a specimen of an adult female collected near Eldari village located in the Eldari valley (Georgia, then Georgian SSR of the USSR) (Dzhaparidze, 1950). Since its description, only a couple dozen papers have been published, mainly documenting findings of the species in different areas or on various hosts. Only fragmentary information on its biology and ecology can be gleaned from the published literature.

Ixodes eldaricus is the member of the subgenus Ixodes (s. str.). The species was considered closely connected with representatives of the persulcatus group (Filippova, 1974, $1977,2008)$. Later the species was included together with I. redikorzevi Olenev, I. occultus Pomerantzev and I. laguri Olenev in a newly created redikorzevi group (Filippova, 2008).

The range of I. eldaricus includes the Crimea, the Caucasus (Georgia, Armenia, Azerbaijan, and Dagestan of Russia), Central Asian states (Turkmenistan, Tadzhikistan, Uzbekistan, southern parts of Kazakhstan and Kirgizstan), Iraq and Israel (Filippova, 1974, 1977; Kolonin, 1981). The tick inhabits mountain forests at 300 to $1,800 \mathrm{~m}$ above sea level (a.s.l.). Adults parasitize birds, while preadults parasitize birds as well as some small mammals (rodents and insectivores). Nymphs and adult ticks were found on spring migrating birds in Cyprus (Kaiser et al., 1974),
Poland (Nowak-Chmura, 2012) and in Turkey (Keskin and Erciyas-Yavuz, 2019). The morphological description of all parasitic stages of I. eldaricus as well as the available data on its ecology and biology were summarized by N.A. Filippova (1974, 1977).

In Israel I. eldaricus was first collected from the rock partridge, Alectoris graeca Meisner (apparently, its eastern equivalent the Chukar partridge, A. chukar [J.E. Gray]), about $20 \mathrm{~km}$ south of Jerusalem, this finding being first attributed to a new species Ixodes tatei Arthur described by Arthur $(1959,1968)$ on the basis of findings in Iraq. Later I. tatei was synonymized with I. eldaricus (Filippova, 1974). Yeruham et al. (1995) collected all stages of $I$. eldaricus on the western foothills of Judea (30 km west of Jerusalem) by dragging and flagging. Larvae were also collected from 2 species of rodents, Acomys cahirinus (É. Geoffroy) and Mus musculus L.

The results of our survey of I. eldaricus including data on size and weight characteristics and biological patterns of this tick are presented below.

\section{MATERIALS AND METHODS}

The site of the survey is located in a hilly area of the Judean Mountains in the western part of Judea $(20 \mathrm{~km}$ west from Jerusalem). The area is covered with natural Mediterranean forests as well as with planted pine trees. Southwestern (with a creek drying in the summer) and northeastern slopes of a valley along the road Abu-Gosh Nataf at 550 to $600 \mathrm{~m}$ a.s.l. $\left(31^{\circ} 82^{\prime} \mathrm{N}, 35^{\circ} 09^{\prime} \mathrm{E}\right)$ were under observation. Ticks were collected by flagging (a white flannel flag by 1x1 m) during October-April 2006/2007. The collections were carried out twice per month on both 
slopes, along roads, which are rarely used. Two collectors worked at each site for 45 to $60 \mathrm{~min}$. The tick abundance was estimated as the number of ticks collected by 1 person during 1 hour. During a total of 45 hours of collection, over 200 ticks (adults and nymphs) were collected. The average daily and monthly temperatures in Jerusalem area, multiannual and for the period of the survey, were taken from the archive of the Central Bureau of Statistics (Israel) (http://www.cbs.gov.il). Twice during that period goats from a farm nearby were inspected. An attempt was also undertaken to collect ticks in the area of Yeruham's survey (1995); sporadic attempts of collecting ticks in different areas of Jerusalem and its suburbs were made in February-March 2008 and in summer months (May to September), 2011.

A sample of ticks from our collections (in total 20 males, 25 females, and 20 nymphs) were measured under stereomicroscope with ocular micrometer. Ticks (in total 46 males, 69 females, and 36 nymphs) were also weighed on an electronic scale.

Observations on some features of tick behavior were carried out using ticks collected in the field. Adults of different size ("big" and "small" according visual estimation) in various numbers and combinations were put into glass tubes immediately after collecting; the time before mating and the influence of tick size on mating were noted. A total of 43 males and 76 females collected in FebruaryMarch were used in these tests. Tick affinity for attacking and biting humans was checked by regular crossexaminations of collectors' clothes and in special tests made in the laboratory. For this purpose, a number of unfed females were placed after collection into speciallyequipped glass tubes (Uspensky, 1967) where a gradient of humidity (65-95\% RH) was created along the length of each tube (Shashina and Ioffe, 1980). The tests were carried out at the next day after tick collection. The ticks were individually put on the researcher's arm and were observed for up to 1 hour. The temperature in the laboratory was $23-25^{\circ} \mathrm{C}$. A total of 15 females collected in October-November and of 20 females collected in March were used in the tests.

\section{RESULTS}

\section{Occurrence}

First ticks were collected in November and the tick activity was observed till the end of April. Adult ticks were regularly collected during the entire period of observation. Single nymphs were sporadically collected during the same period with an obvious increase in March. Not a single larval specimen was found. Ticks were collected only from the grass slightly above the ground and were never found on higher vegetation. When on the flag, they did not demonstrate any activity, passively remaining in one spot on the flag. The results of tick collections on the southwestern slope are presented on Fig. 1. The adult tick activity was higher in the beginning of the activity season (November-December) and in its second part (FebruaryMarch) with a strong decline in January. The numbers of ticks collected on the northeastern slope was much smaller and those data are omitted.

Mean daily air temperatures in November-December, 2006 were lower than the mean daily multiannual temperatures of those months, while in January-April, 2007 mean daily temperatures were higher than the mean multiannual ones (Fig. 2). January was characterized by a strong decline of maximal and minimal daily temperatures.

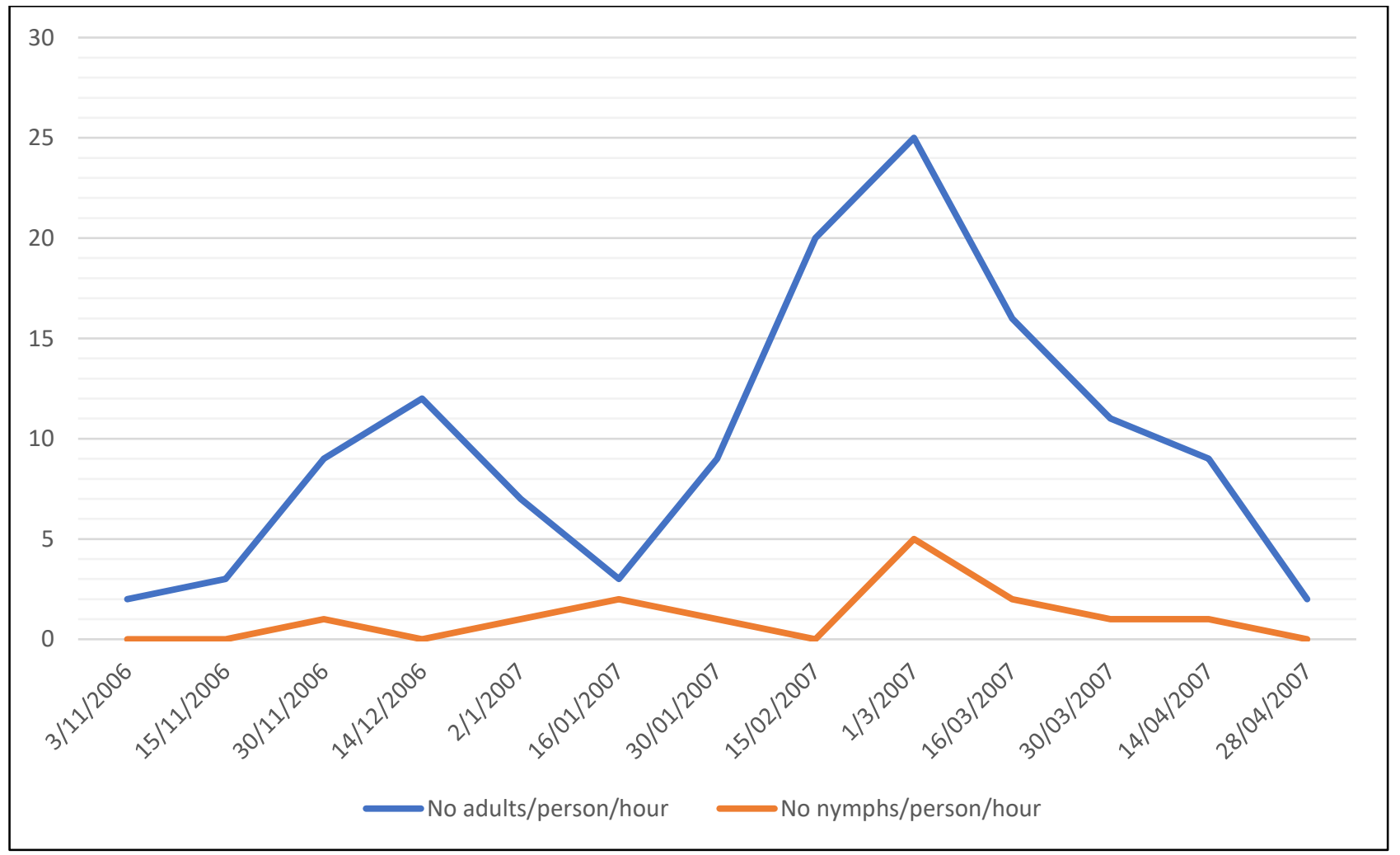

Figure 1. No of ticks collected in the survey area (vertical axis - No of ticks). 


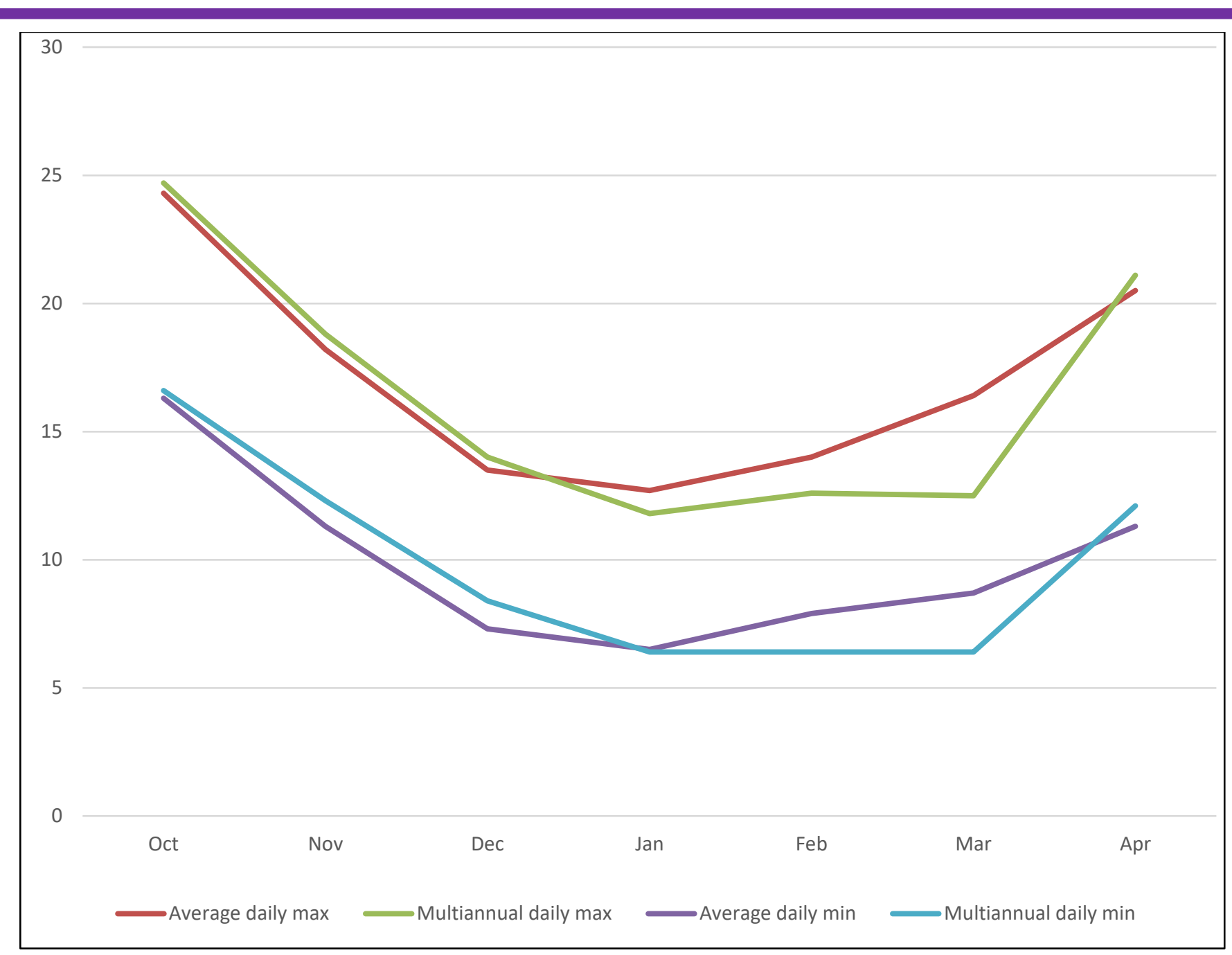

Figure 2. Maximal and minimal average daily temperatures: in the season 2006/2007 and multiannual (vertical axis temperature in ${ }^{\circ} \mathrm{C}$ ).

Table 1. Size and weight characteristics of unfed nymphal and adult I. eldaricus [Mean \pm SD, (range)].

\begin{tabular}{llll}
\hline Characteristics & Nymphs & \multicolumn{2}{c}{ Adults } \\
\cline { 3 - 4 } & & Males & Females \\
\hline $\begin{array}{l}\text { Scutum (conscutum } \\
\text { for males), mm } \\
\text { width }\end{array}$ & $0.527 \pm 0.051(0.439-0.610)$ & $1.84 \pm 0.10(1.66-2.00)$ & $0.91 \pm 0.07(0.78-1.03)$ \\
$\begin{array}{l}\text { Alloscutum, mm } \\
\text { length }\end{array}$ & $0.451 \pm 0.058(0.366-0.561)$ & $0.98 \pm 0.07(0.87-1.10)$ & $2.17 \pm 0.11(2.00-2.39)$ \\
$\begin{array}{l}\text { Width } \\
\text { Weight, mg }\end{array}$ & $0.992 \pm 0.065(0.875-1.078)$ & & $1.35 \pm 0.09(1.19-1.51)$ \\
& $0.12 \pm 0.01(0.085-0.15)$ & $0.79 \pm 0.11(0.45-1.0)$ & $1.18 \pm 0.27(0.6-1.9)$ \\
\hline
\end{tabular}

When goats from the farm located near-by that had been pastured over the sites of survey were examined, we found no Ixodes ticks but only a small number of ticks of the genus Haemaphysalis.

An attempt to collect ticks at the site of previous collections (Yeruham et al., 1995) was unsuccessful: not a single specimen was found. Additionally, one male of I. eldaricus was collected by flagging grass vegetation in the southern part of Jerusalem, in a woody ravine dividing two residential areas in March, 2008. No ticks were found in summer months.

Size and weight characteristics

The measurements of the scutal/conscutal length and width for males, females and nymphs and of the alloscutal length and width for females and nymphs as well as the weights of ticks from these groups are presented in Table 1. 
Biological patterns

No adults in the mating position were found during tick collection. However, when collected ticks of different sex were put together in the same tubes, it took 1 to $3 \mathrm{~min}$ for ticks to be in the mating position. Large females were preferable for males and large males had advantage over small males. In any case, mating took place regardless of the male size. Interestingly, these patterns of behavior were consistently observed in all of our tests.

Not a single tick was found on the collector's clothes during tick collection. When unfed females were put on a human arm, no cases of tick attachment were observed (Table 2). More than $80 \%$ of ticks left the arm after 30 min of observation and more than $90 \%$ after 45 min.

Table 2. Affinity for attacking humans in unfed I. eldaricus females.

\begin{tabular}{|c|c|c|c|c|c|c|c|}
\hline \multicolumn{2}{|l|}{ Ticks } & \multicolumn{4}{|c|}{ No. ticks left on the arm, min } & \multirow{2}{*}{$\begin{array}{l}\text { No. ticks kept } \\
\text { on the arm af- } \\
\text { ter } 1 \mathrm{~h}\end{array}$} & \multirow{2}{*}{$\begin{array}{l}\text { No. ticks at- } \\
\text { tached to the } \\
\text { arm }\end{array}$} \\
\hline Collected in & No. & $<15$ & $16-30$ & $31-45$ & $46-60$ & & \\
\hline October-November & 15 & 4 & 8 & 2 & 0 & 1 & 0 \\
\hline March & 20 & 8 & 10 & 1 & 1 & 0 & 0 \\
\hline
\end{tabular}

\section{DISCUSSION}

Although I. eldaricus inhabits xerophilous mountain forests and bush, the tick avoids both very high and very low temperatures and prefers habitats, characterized by adequate humidity. This is indicated by the differences in the seasons of activity of the tick (spring and autumn months in the northern part of the range (Filippova, 1977) and winter months in our observations and in those by Yeruham et al. (1995), and by its preferential occurrence in the areas characterized by higher humidity and lower sun irradiation in our and Yeruham's observations. A bimodal activity pattern with a strong decline of activity in January observed in our survey is also common to I. ricinus near the southern border of its range (Daniel et al., 2015; Aydin et al., 2020). Our data allow to estimate the average daily maximal air temperatures in the range of $13-20^{\circ} \mathrm{C}$ as optimal for activity of adult I. eldaricus. The minimal daily temperatures appear less essential since their values in December and February were close to those in January (Fig. 2) and did not suppress high tick activity. It is unclear whether the differences in temperatures of the $2006 / 2007$ season from multiannual ones (lower in October-December and higher in February-March) influenced the tick activity pattern. Our observation on tick abundance dynamics during the season of their activity is a first attempt of such kind. We have no ready explanation for the absence of larval ticks in our collections as compared with data by Yeruham et al. (1995).

The habitats of I. eldaricus usually look as "spots" among xerophilic vegetation typical for the entire range of this species. Tick location in the lowest level of the vegetation and their low activity determine various degrees of isolation of I. eldaricus populations from each other with possible connection provided only by the bird hosts. Our lack of success in finding ticks at the site of Yeruham's collections may be explained by a drastic decrease in soil humidity following the planting of eucalyptus trees in the area. In the Crimea, this species has been classified as "disappearing" (Nebogatkin, 1998) because of anthropogenic destruction of its habitats and reduction of host populations in the 1990s. Gradual warming of the Earth's temperature in the past decades may also be an unfavorable factor for I. eldaricus populations.

Since I. eldaricus is characterized by low abundance, low activity and specificity in locations and hosts (and is not of the primary interest of researchers), its geographic range is insufficiently described. Main hosts of I. eldaricus in all parasitic stages are ground-foraging passerine birds, many of them with a limited distance of seasonal migrations. Findings of specimens of this tick on migrating birds in Cyprus (Kaiser et al., 1974) and Turkey (Keskin and Erciyas-Yavuz, 2019) were thought to be the result of bird infestation in the same or adjacent countries. It was also suggested that this species should be present in Iran (Filippova et al., 1976). Most probably, isolated populations of I. eldaricus can be found in Lebanon and western part of Syria. Long-distance introduction of specimens of this species is extremely rare; only one case of such kind has been documented to date (Nowak-Chmura, 2012).

Ixodes eldaricus was first considered closely connected with the species from the persulcatus group (Filippova, $1974,1977)$ but later it was included in a newly created redikorzevi group (Filippova, 2008). It may be informative to compare our data with the corresponding published data on both of these groups.

The scutum of I. eldaricus nymphs from our collections is a little shorter (but statistically significantly, according to the Student's $t$-criterion $=4.58$ ) than that of nymphal $I$. eldaricus from other parts of the range (Filippova, 1974, 1977). It might be explained by the fact that the area of our survey is located in the southernmost part of the tick range where the conditions are less favorable than in the main part of its range. At the same time, it is comparable with the data for I. redikorzevi and I. occultus but less than that of the ticks from the persulcatus group (Filippova, 1977). The weight of I. eldaricus nymphs is a little less than that of nymphal I. persulcatus and I. ricinus, while the weight I. eldaricus females is about half that of the two species mentioned above (Uspensky et al., 1999). It means that nymphs of I. eldaricus engorge less blood than the ticks of the persulcatus group. Using the data on feeding of adult I. redikorzevi obtained by Tiflova (1974), we 
can assume that the mean weight of engorged I. eldaricus females could not exceed $100 \mathrm{mg}$.

No copulating pairs of I. eldaricus adults were found during tick collection which strongly differs from I. persulcatus or I. ricinus whose adults were regularly found in the mating position (Ioffe-Uspensky and Uspensky, 2017). However, field-collected males and females of I. eldaricus mated immediately after being placed together in the same tube, similarly to I. persulcatus specimens. Interestingly, in our previous experiments with a laboratory colony of I. persulcatus (Uspensky and Repkina, 1978), virgin adults could be together in the tube for up to 31 days making no attempt to mate. It is possible that pheromone regulation is fully manifested only in the field populations of adult Ixodes ticks and is suppressed in the laboratory conditions. The absence of copulating I. eldaricus adults in the field puts question on pheromone regulation in this species as compared with I. persulcatus and I. ricinus ticks where such regulation does exist (Uspensky and Yemel'yanova, 1980; Háiková and Leahy, 1982).

Adult I. eldaricus did not show any aggressiveness toward humans while I. persulcatus is a very aggressive species (Uspensky, 1993, 2016). This is in agreement with Filippova's observations $(1974,1977)$ that I. eldaricus was not found attacking humans in nature. A tick species which have no epidemiological significance might, however, have certain significance in epizootiology of known and unknown infections. For example, such species as $I$. arboricola, another poorly-studies species, only recently was found to participate in circulating several rickettsia species among bird hosts (Špitalská et al., 2011). Considering that I. eldaricus can be found in areas where Rickettsia conorii israelensis and other rickettsial agents are spread (Guberman et al., 1996; Mumcuoglu et al., 2002; Rose et al., 2017), the necessity of studying the role of this species in epizootiology of these pathogens is important.

It would be informative to test Israeli I. eldaricus for Borrelia burgdorferi s.l., especially in view of the following considerations:

(i) The range of I. ricinus, one of the main vectors of that pathogen, covers the territory of the Levant from Turkey (Bursali et al., 2012) to the northern part of Israel (Erster et al., 2013) (although there is no data from Lebanon and the western part of Syria, it would be reasonable to assume that this tick populates the forested areas of these countries, especially the mountain forests). Borrelia burgdorferi s.l. was isolated from I. ricinus in Turkey (Güner et al., 2003; Polat et al., 2017) and a systematic review of the available data (Önal et al., 2019) indicates that Lyme borreliosis is a major health concern in the country;

(ii) Ground-foraging passerine birds are important hosts for I. ricinus and dominant hosts for I. eldaricus, a number of species being common for both tick species (Filippova, 1977). These bird species are not only good tick carriers, but also competent reservoirs of several genospecies of $B$. burgdorferi (Comstedt et al., 2006; Taragel'ová et al., 2008; Norte et al., 2012); (iii) The routes of seasonal migrations of many passerine birds between Europe and Eastern Africa lie through Israel and Turkey (Inci et al., 2016) with stopover sites in both countries (Frumkin et al., 1995; Inci et al., 2016), which provides favorable conditions for circulation of ticks and tick-borne pathogens throughout the Levant.

When these facts are considered together, it appears rather likely that $B$. burgdorferi circulates between birds and ticks in forested areas of Israel, and that I. eldaricus is one of the tick species mediating this process.

\section{Statement of ethics approval}

Not applicable.

Funding

There is no fund for the present study.

\section{Conflict of interest}

There is no potential conflict of interest.

\section{Acknowledgments}

The author is greatly indebted to H. Uspensky for participation in tick collection. The excellent linguistic assistance by Dr. I. Ouspenski is acknowledged. Comments of an anonymous reviewer were very helpful.

\section{REFERENCES}

Arthur, D.R. 1959. Ixodes tatei n.sp. from Iraq (Acarina: Ixodidae). Parasitology, 49: 108-110.

Arthur, D.R. 1968. The immature stages of Ixodes tatei Arthur (Ixodidae). Parasitology, 58: 165-169.

Aydin, L., Girişgin, O., Özüiçli, M., Girişgin, A.O. and Coşkunserçe, G. 2020. Potential risk in public parks: Investigation of the tick species (Acari: Ixodida) in Bursa metropolitan area, Turkey. Ankara Üniversitesi Veteriner Fakültesi Dergisi, 67: 393-397. doi:10.33988/auvfd.658135

Bursali, A., Keskin, A. and Tekin, S. 2012. A review of the ticks (Acari: Ixodida) of Turkey: Species diversity, hosts and geographical distribution. Experimental and Applied Acarology, 57: 91-104. doi:10.1007/s10493-012-9530-4

Comstedt, P., Bergström, S., Olsen, B., Garpmo, U., Marjavaara, L., Mejlon, H., Barbour, A.G. and Bunikis, J. 2006. Migratory passerine birds as reservoirs of Lyme borreliosis in Europe. Emerging Infectious Diseases, 12: 1087-1095.

Daniel, M., Malý, M., Danielová, V., Kř́iž, B. and Nuttall, P. 2015. Abiotic predictors and annual seasonal dynamics of Ixodes ricinus, the major disease vector of Central Europe. Parasites \& Vectors, 8: 478. doi:10.1186/s13071-015-1092-y 
Dzhaparidze, N.I. 1950. New species of ticks of the family Ixodidae in Georgia. Soobshcheniya Akademii Nauk Gruzinskoi SSR, 2: 117-121. [In Russian]

Erster, O., Roth, A., Hadani, Y. and Shkap, v. 2013. First detection of Ixodes ricinus on beef cattle in Israel. Veterinary Parasitology, 191: 394-399.

doi:10.1016/j.vetpar.2012.09.008

Filippova, N.A. 1974. Ixodes eldaricus and its distribution in the south of the USSR. Parazitologiya, 8: 504-514 [In Russian] (English translation: NAMRU-3 T-1554).

Filippova, N.A. 1977. Ixodid ticks of the subfamily Ixodinae. Fauna of the USSR, Arachnoidea 4 (4). Nauka, Leningrad, Russia, 396 pp. [In Russian]

Filippova, N.A. 2008. Characteristic features of the categories "genus" and "subgenus", and the intercalary category "group of species" in ixodid ticks (Acari: Ixodidae). Parazitologiya, 42: 249-263. [In Russian]

Filippova, N.A., Neronov, V.M. and Farhang-Azad, A. 1976. Materials on the fauna of ixodid ticks (Acarina, Ixodidae) from small mammals in Iran. Entomologicheskoye Obozreniye, 55: 467-479. [In Russian]

Frumkin, R., Pinshow, B. and Kleinhaus, S. 1995. A review of bird migration over Israel. Journal für Ornithologie, 136: 127-147.

Guberman, D., Mumcuoglu, K.Y., Keysary, A., IoffeUspensky, I., Miller, J. and Galun, R. 1996. Prevalence of spotted fever group rickettsiae in ticks from southern Israel. Journal of Medical Entomology, 33: 979982.

doi:10.1093/jmedent/33.6.979

Güner, E.S., Hashimoto, N., Takada, N., Kaneda, K., Imai, Y. and Masuzawa, T. 2003. First isolation and characterization of Borrelia burgdorferi sensu lato strains from Ixodes ricinus ticks in Turkey. Journal of Medical Microbiology, 52: 807-813. doi:10.1099/jmm.0.05205-0

Hájková, Z. and Leahy, M.G. 1982. Pheromone-regulated aggregation in larvae, nymphs and adults of Ixodes ricinus (L.) (Acarina, Ixodidae). Folia Parasitologica, 29: 61-67.

Inci, A., Vildirim, A., Duzlu, O., Doganay, M. and Aksoy, S. 2016. Tick-borne diseases in Turkey: A review based on One Health perspective. PLoS Neglected Tropical Diseases, 10 (12): e0005021. doi:10.1371/journal.pntd.0005021

Ioffe-Uspensky, I. and Uspensky, I. 2017. The influence of preprandial insemination on feeding and oviposition of Ixodes persulcatus females (Acari: Ixodidae) and some thoughts concerning mating strategies in ticks of the genus Ixodes. Ticks and Tick-borne Diseases, 8: 866-871.

doi:10.1016/j.ttbdis.2017.07.003
Kaiser, M.N., Hoogstraal, H. and Watson, G.E. 1974. Ticks (Ixodoidea) on migrating birds in Cyprus, fall 1967 and spring 1968, and epidemiological considerations. Bulletin of Entomological Research, 64: 97-110.

Keskin, A. and Erciyas-Yavuz, K. 2019. Ticks (Acari: Ixodidae) parasitizing passerine birds in Turkey with new records and new tick-host associations. Journal of Medical Entomology, 56: 156-161. doi:10.1093/jme/tjy151

Kolonin, G.V. 1981. World Distribution of Ixodid Ticks. The Genus Ixodes. "Nauka", Moscow, 116 pp. [In Russian]

Mumcuoglu, K.Y., Keysary, A. and Gilead, L. 2002. Mediterranean spotted fever in Israel: A tick-borne disease. The Israel Medical Association Journal, 4: 44-49.

Nebogatkin, I.V. 1998. Rare, disappearing and occasionally occurred species of ixodid ticks (Parasitiformes, Ixodidae) in Ukraine. Vestnik Zoologii, 32: 143-147. [In Russian]

Norte, A.C., Ramos, A., Gern, L., Núncio, M.S. and Lopes de Carvalho, I. 2013. Birds as reservoirs for Borrelia burgdorferi s.l. in Western Europe: Circulation of $B$. turdi and other genospecies in bird-tick cycles in Portugal. Environmental Microbiology, 15: 386-397. doi:10.1111/j.1462-2920.2012.02834.x

Nowak-Chmura, M. 2012. Ixodes eldaricus Djaparidze, 1950 (Ixodidae) on migrating birds - reported first time in Poland. Veterinary Parasitology, 186: 399-402. doi:10.1016/j.vetpar.2011.11.029

Önal, U., Erdem, H.A., Önal, A.U. and Sipahi, O.R. 2019. Systematic review of Lyme disease in Turkey. Tropical Doctor, 49: 165-170. doi:10.1177/0049475519843387

Polat, E., Sirekbasan, S., Gokalp, H. and Kutlubay, Z. 2017. Epidemiological distribution of ticks analyzed at our laboratory between April 2008 and November 2015; A study of Borrelia burgdorferi in Ixodes. Eurasian Journal of Medicine and Oncology, 1: 124-128. doi:10.14744/ejmo.2017.36854

Rose, J., Nachum-Biala, Y., Mumcuoglu, K.Y., Alkhamis, M., Ben-Nun, A., Lensky, I., Klement, E., Nasereddin, A., Abdeen, Z.A. and Harrus, S. 2017. Genetic characterization of spotted fever group rickettsiae in questing ixodid ticks collected in Israel and environmental risk factors for their infection. Parasitology, 144: 10881101.

doi:10.1017/S0031182017000336

Shashina, N.I. and Ioffe, I.D. 1980. Egg development in some species of ixodid ticks (Ixodidae) under conditions of different humidity. Meditsinskaya Parazitologiya I Parazitarnye Bolezni, 49 (5): 79-85. [In Russian] 
Špitalská, E., Literák, I., Kocianová, E. and Taragel'ová, V. 2011. The importance of Ixodes arboricola in transmission of Rickettsia spp., Anaplasma phagocytophilum, and Borrelia burgdorferi sensu lato in the Czech Republic, Central Europe. Vector-borne and Zoonotic Diseases, 11: 1235-1241.

doi:10.1089/vbz.2010.0210

Taragel'ová, V., Koči, J., Haninková, K., Kurtenbach, K., Derdáková, M., Ogden, N.H., Literák, I., Kocianová, E. and Labuda, M. 2008. Blackbirds and song thrushes constitute a key reservoir of Borrelia garinii, the causative agent of borreliosis in Central Europe. Applied and Environmental Microbiology, 74: 1289-1293.

doi:10.1128/AEM.01060-07

Tiflova, L.A. 1974. Patterns of ecology of the tick Ixodes redikorzevi redikorzevi 0l. 1927 in the Ciscaucasus and its role in epidemiology of tularemia. Author's summary of PhD Dissertation. Zoological Institute, Leningrad, 21 pp. [In Russian]

Uspensky, I.V. 1967. On the susceptibility of Ixodes persulcatus P.Sch. ticks to DDT and other pesticides in Western Sayan, USSR. World Health Organization working paper, WHO/VBC/67.4.

Uspensky, I. 1993. Ability of successful attack in two species of ixodid ticks (Acari: Ixodidae) as a manifestation of their aggressiveness. Experimental and Applied Acarology, 17: 673-683.
Uspensky, I. 2006. Top ten ticks. Letter to the editor. Newsletter on ticks and tick-borne diseases of livestock in the tropics, 29: 30-32.

Uspensky, I. 2016. The taiga tick, Ixodes persulcatus Schulze (Acari: Ixodida: Ixodidae). In: Lyme Disease. SMGroup e-book, Available http://www.smgebooks. com/lymedisease/chapters/LD-16-02.pdf

Uspensky, I., Ioffe-Uspensky, I., Mumcuoglu, K.Y. and Galun, R. 1999. Body weight characteristics of some ixodid ticks: Reflecting adaptations to conditions of their habitats? In: Ecology and Evolution of the Acari. Bruin, J., van der Geest, L.P.S. and Sabelis, M.W. (Eds). Kluwer Academic Publishers, Dordrecht, The Netherlands, 657-665.

Uspensky, I.V. and Repkina, L.V. 1978. Some observations on mating and fertilization of Ixodes persulcatus. Zoologicheskii Zhurnal, 57: 1092-1095. [In Russian]

Uspensky, I.V. and Yemel'yanova, O.Y. 1980. On the existence of pheromone relationships in ticks of the genus Ixodes. Zoologicheskii Zhurnal, 59: 699-704 [In Russian] (English translation: NAMRU-3 T-1447).

Yeruham, I., Hadani, A., Galker, F. and Rosen, S. 1995. The occurrence of Ixodes eldaricus (Dzhaparidze, 1950) (Acarina: Ixodidae) in Israel. Acarologia, 36: 191-193.

Edited by: Kosta Y. Mumcuoglu

Reviewed by: Two anonymous referees

Citation: Uspensky, I. 2021. The Eldari tick Ixodes eldaricus (Acari: Ixodidae) in Israel: its occurrence, morphometric and biological characteristics. Acarological Studies, 3 (1): 9-15. 